\title{
Physical Examination Result Standard Unit
}

National Cancer Institute

\section{Source}

National Cancer Institute. Physical Examination Result Standard Unit. NCI Thesaurus.

Code C83361.

The standard unit of measure for physical examination results. 